\title{
APOBEC3F Gene
}

National Cancer Institute

\section{Source}

National Cancer Institute. APOBEC3F Gene. NCI Thesaurus. Code C95272.

This gene plays a role in the viral defense response. 